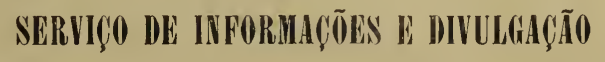

\title{
PLANTAS UTEIS DO DESERTO
}

\section{Henrique @emler}

Publicação autorizada pelo Exmo. Sr. Ministro da Agricultura, Industria e Commercio,

\section{DR. PEDRO DE TOLEDO}

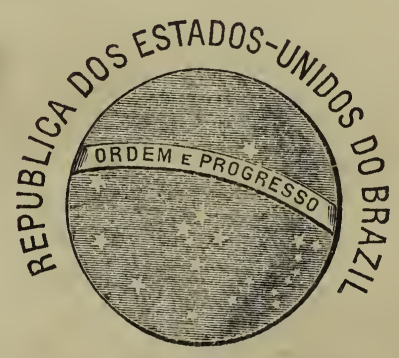

RIO DE: JANEIRO

Typographia do Serviço de Fistatistica.

$1 \overline{913}$ 


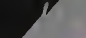




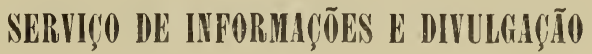

\section{PLANTAS UTEIS DO DESERTO}

\section{Henrique @emler}

Publicação autorizada pelo Exmo. Sr. Ministro da Agricultura, Industria e Commercio,

\section{DR. PEDRO DE TOLEDO}

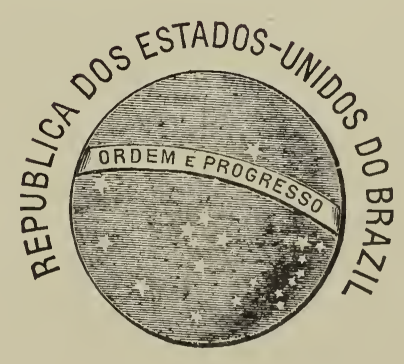

RIO DE JANEIRO

Iypographia do Sexviço de Estatistiea 
Digitized by the Internet Archive in 2017 with funding from

University of Illinois Urbana-Champaign Alternates

https://archive.org/details/plantasuteisdode00seml 


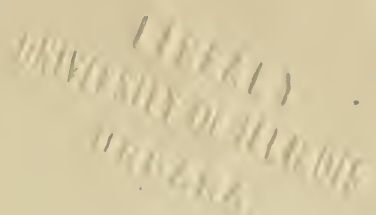

\section{INTRODUCÇÃO}

O Serviço de Informações e Divulgação do Ministerio da Agricultura, autorizado pelo titular dessa pasta, exm. sr. dr. Pedro de Toledo, iniciou ha pouco a publicação da ultima parte do notavel e interessante trabalho de Henrique Semler, intitulado "A Agricultura nas Regiões Tropicaes", vertido para o vernaculo pelo dr. Frederico Draenert, tendo sido a primeira parte da referida obra publicada em I908, em dois grossos volumes, sob o titulo Manual para Agricultores e Commerciantes.

A importante e minuciosa monographia sobre as PLANTAS UTEIS DO DESERTO - objecto do presente volume, é a segunda publicação da série dos valiosos estudos inclusos no citado trabalho de Henrique Semler, que o Serviço de Informações expõe á luz da publicidade, tendo já publicado o RAMI, na certeza de prestar inestimavel serviço ás classes laboriosas e productoras do Brasil, fornecendo-lhes ensinamentos sobre uma industria que muitos proventos poderá trazer ao nosso paiz, quando fôr scientificamente explorada.

Após esta, serão successivamente publicadas e distribuidas outras monographias agricolas egualmente interessantes, extrahidas do notavel trabalho de Semler, o qual, embora escripto ha alguns annos, applica-se perfeitamente ás exigencias e necessidades actuaes, tornando-se, por isso, de grande vantagem, divulgar os conhecimentos que clle encerra e os ensinamentos pelo mesmo preconizados. Em todos os trabalhos dessa série, que se forem publicando, o Serviço de Informações irá annexando algumas notas elucidativas e de actualidade, sobre os pontos necessarios, para melhor comjrehensão do leitor.

Julgamos mais pratico i'csdobrar assim, em monographias, ce restante da obra de Henrique Semler, para que, com ma:or faciildade, os interessados encontrem, manuseiem e estudem o assumpto que escolherem e preferirem.

Rio, outubro de I9rz.

O DIRECTOR. 



\section{PLAN'TAS U'TEIS DO DESERTO}

(HENRIQUE SEMLER)

( PEOEMIO )

Ha muitos annos, em dia de sol estival, estavamos em um dos mais altos cumes da parte meridional de Serra Nevada, olhando para oéste, para a California, e voltámo-nos depcis para o levante, onde os montes da Nevada, com matizes azulados, limitavam o horizonte. Não se avistava um só ponto, onde o olhar se pudesse regozijar com a verdura, e, involuntariamente ncs vieram aos labios as palavras: "Deserto! Deserto triste, inutil! Eternamente os homens fugirão de ti !"

Nesse momento sentimos que nos tocavam ao hombro: "Amigo, não ha deserto!" Quem tal dizia era um naturalista escossês, um desses humens raros, que se nã occupam, assentados no acanhado gabinete de estudo, em distillar um thesouro de conhecimentos das pesquizas dos outros, mas vivem sempre no meio da natureza, para desvendar os seus segredos, desdenhando disputas sobre hypotheses scientificas, provaveis, mas ainda não comprovadas, afim de observar o nascimento, o crescimentc e a morte na natureza.

Sacudimos a cabeça, ouvindo essa these ousada e sua justificação. Mas ganhámos experiencia. Vimos transformar-se ante nossos olhos tantos desertos em campos florescentes, vimos tantos homens, que si melhor pensavam mais energicamente agiam, vencerem e dominarem ondas de areia e terrenos rochosos, que aprendemos a nos inclinar perante o facto, entoando o hymno do novo evangelho: Não ha deserto!

Não! No sentido vulgar la palavra, não ha deserto. Digam o que quizerem a superstição e a ignorancia. Neste mundo, criado por Deus, não ha lugar condemnado á eterna esterilidade. Qualquer ponto da terra póde ser utilizado; si o não fôr, a culpa é da myopia humana.

Pedem-nos provas. Bem. Quem hoje subir áquelle cume, em que nos achavamos então, não verá mais um deserto desolador. Verá oasis risonhos, laranjaes, jarơins em flôr que embellezam a paisagem e cada anno mais e mais se multiplicam, até que em futuro proximo todo o terreno será transformado em campcis e pomares ferteis. 
Destacam-se muitos campos azues - são culturas de alfafa, iniciadas em terrenos que eram outr'ora pastos połres de ovelhas. Para nutrir uma ovelha, julgaram necessarios oito hectares, sendo condição precisa para isso a precipitação regular da quantidade média da chuva. Deram-se, porém, seccas frequentes, que forçaram us habitantes a levar os rebanhos á procura de pasto, além da montanha e, no caminho, a fome dizimou-os cruelmente. 'T'entaram então leval-os ao littoral, para, ao menos, salvar os couros e o cebo; os cadaveres foram presa das ondas do Oceano. Agora cultivam alfafa, que, com o auxilio da irrigação artificial, dá por anno oito collheitas, e a mesma superficie, que outr'ora apenas nutria uma ovelha, alimenta hoje, com toda a fartura, vinte. Isso não será um triumpho magnifico da energia e do espirito emprehendedor dc's homens?

Além nas grutas e nos valles estreitos, inaccessiveis á charrúa, encontram-se espalhados estabelecimentos de apicultores. Algumas plantas do deserto, que se multiplicam por sementeira e amanhos, fornecem pelas suas flôres superior mel ás abelhas. Essse mel é um dos productos mais impurtantes de exportação da California meridional.

Do nosso ponto de observação, avista-se um valle entre rochas tristes e sombrias. Depois do valle de Jericó, é o de depressão mais profunda, abaixo do nivel do mar; tem o nome lugubre de $V$ alle da Morte porque, ha muitos annos, uma pequena caravana de immigrantes, vinda de léste, perdeu-se nessa caldeira sinistra de monte e morreu a sêde. Desde então diziam que no Valle da Morte não poderia viver planta, nem animal; os proprios indios asseveravam que uma ave, que tentasse voar por cima delle, cahiria morta, tão prenhe de veneno era o ar que nascia das fendas escuras das rochas e das areias calidas no fundo do valle. Nãc' ha duvida: esse pedaço de terra estava condemnado á esterilidade.

Hoje ha uma actividade de formigas no calumniado valle. Homens energicos, não temendo os seus horrores, souberam tirar-lhe o encanto, desde que, sob uma camada pouco espessa, no fundo, acharam mina riquissima de boraxita. O ferro da broca, furando um poço artesiano, descobriu agua potavel, e como a escarnecer da superstição, da ignorancia e da pusilanimidade dos antigos, echôa o silvo da lccomotiva nas ingreme's paredes rochosas.

Chama-se agora Arizona o paiz mysterioso de Cibola, que os Azteques indicavam, quando os conquistadores hespanhoes, rudes e grosseiros, perguntavam pela fonte dos seus thesouros. Curtez mesmo sahiu para procural-o, e embora regressasse desenganado, o seu exemplo foi, todavia, imitado por ousados aventureiros, até que descobriram a região procurada. Comtudo os hespanhóes nunca puderam manter-se em Cibcla, não obstante sua ambição e ganancia de prata, a intrepidez e coragem em soffrer privações. Duas palavras os justificam: deserto e indios. Desertos alcalinos, poeirentos, queimados pelo sol; terra, montanhosa, solitaria, núa, sem agua, e os Apaches, indios nomades e sanguisedentos.

Quando atravessámćs pela primeira vez o paiz, já tinham conseguido alguma cousa, todavia não hesitamos nem um momento em negar qualquer futuro a Arizona: aqui homens brancos nunca estabelecerão civilização persistente, fundando-a na agricultura, pensavamos nós. Nas margens de dous out tres rios, que ha, e que seccam durante a estação calmosa, płderia, porventura, realizar-se, 
por meio de irrigação artificial, uma cultura limitada do sólo? Pouco distante delles a natureza apresentava o verdadeiro caracter do deserto: cada planta estava armada de espinhos, cada animal de garras. Com a areia solta brincava o vento; os olhurs doloridos fechavam-se ante o reflexo do sol batendo na areia e nas parede's das rochas núas.

Dez annos mais tarde, lembravamo-nos envergonhados da nossa prophecia. Uma ferro-via, que ligava dous oceanos, já atravessava a paiz, os indios eram mansos, mineiros ousados fundaram cidades, em seguida vieram pastores e depois agricultores. Procuraram a agua que faltava, e acharam-na no seio da terra; debellaram a falta das chuvas pela construcção de açudes e reprezas nos rios. Verificámos que Arizona, com seus pecegos e uvas magnificas, rivalizava, vaníajosamente, com a California, e, onde julgavamos vêr um deserto eterno. ondulavam searas de trigo dourado.

Quem consultar um mappa antigo da America do Norte, nota o territorio a oéste das Montanhas Rochosas até á Nevada, qualificado de "grande deserto norte-americanc". Nos mappas modernos esse deserto já está encerrado em limites muito mais estreitos. No Colorado, em alguns casos numa altitude de I.200 a I.500 metros, começaram a conquistar terreno culto ao deserto. Depois vieram os Mormões e criaram o seu mui fallado e com razão admirado cúsis do grande Lago Salgado. Outros immigrantes succederam áquelles, em grupos pequenos ou isolados, e seguiram o seu exemplo, onde encontraram possibilidade. Os terrenos viridentes, colonizadus, resplandesciam no meio das areias cinzentas e do capim salino, mais cinzento ainda, annunciavam a gloria de homens activos e energicos e nos enchiam de alegria, certos de que a geração vindoura não encontraria mais o "grande deserto americano".

Devemos lembrar aqui um facto pouco conhecido, passado no começo do seculo XIX com duas commissões, uma francêsa e outra inglêsa, que andaram á procura de um porto para estação de carvão, que servisse para a installação de uma colonia, e tocaram justamente no logar onde hoje está edificada a magnifica cidade de Melbcurne. Tanto os francêses, como os inglêses, depois de curta inspecção, levantaram ferro e partiram a informar aos seus governos, em relatorios prolixos, que o sitio onde tocaram era improprio para o estabelecimento de uma colonia e que qualquer tentativa neste sentids seria trabalho perdido. Os francêses e inglêses só viram areia, tufos seccos de capim e alguns arbustos mirrados, ou por outra, viram um deserto na accepção verdadeira da palavra. Fundar aي̣i uma colcnia, seria loucura. Si Melbourne e Colonia são hoje inglêsas, é devido ao merecimento de um punhado daquelles pioneiros da civilização, que na colonização da America, Australia e Africa do Sul, tiveram papel muito preponderante e ainda hoje c têm, los quaes, porém, na historia escripta, si delles se occupam, é para fallar superficialmente ou mesmo com expressões de desprezo, como si fossem unicamente cavadores de ouro sem consciencia, ou aventureiros levianos. Foram homens corajusos, endurecidos no trabalho, que não se aterrorizavam com cousa alguma. Longe das cidades e aldeias, procuravam estabelecer-se, e tantas vezes eran rechassados pelos selvagens, quantas voltavam para reconstruir a choupana queimada. Aproveitamos a opportunidade para recommendar aos historiadores esses pioneiros genuinos, afim de que tenham as 
suas paginas de gloria na historia. Poucas foram as lições que trouxeram da escola, mas possuiam um thesouro inestimavel de experiencia e olhar exercitado para as observações; a sua escola foi a vida de trabalhos assicluos, proseguidos com prazer e dedicação e, com o auxilio dessas duas faculdades adquiridas, estavam habilitados para descobertas e explorações de riquezas naturaes, que, para muitos, sobrecarregados de conhecimentos theoricos, seriam eternamente um livro fechado e inutil.

Foram homens desse quilate que reccnheceram, que uma cidade construida no sitia, onde hoje está Melbourne, teria grande futuro e que os seus arredores poderiam ser transformados em um jardim, logo que fosse possivel descobrir agua. E tambem com elles se verificou a palavra das Santas Escripturas: "Procurai e achareis". Foram igualmente homens desse quilate, que não se atemorizaram, quando thes disseram que a Australia era um grande deserto, sómente cultivavel em alguns pontos de littoral e nas margens de poucos rios. Apezar desses preconceitos, atiraram-se á luta, com vigor e coragem.

O deserto não era tão grande como se suppunha e sua circumferencia real diminue consideravelmente desde meio seculo. As colonias progridem cada vez mais; aos pucos vão se restringindo os limites da região, reputada árida. Mais tarde, provavelmente, tempo virá, em que "o grande deserto australianc" desapparecerá inteiramente como o "grande deserto americano".

A ilha de Ascensão ou Santa Helena que era antigamente? U'm rochedo nú, afastado das costas da Europa. Para ninguem parecia ter valor, nem para homens selvagens, e, quando a Inglaterra tomou posse della, fêl-o por motivos estrategicos. Nenhuma arvore, nem mesme arbusto, sómente capim rarefeito em alguns logares, nem um só animal, nem mesmo agua potavel havia; eis o que era Ascenção, quando uma pequena guarnição inglêsa della tomou posse, a qual com razão podia queixar-se de ter sido desterrada. Felizmente o commandante era um homem bem instruido, cujo horizonte espiritual excedia de muito o seu officio das armas. Em vez de se pôr a fitar a triste ilha com olhos desolados, em vez de perder com os seus soldados o tempo no dolce far niente enervante, esforçou-se em uma empreza, que lhe devia trazer maior gloria do qua o mais brilhante feito de armas: a criação de um jardim e depois de um bosque. Claro é que, sem agua, não podia realizar o seu plano, como não podia utilizar para esse fim a agua potavel, trazida a muito custo da cidade do Cabo; teve de cavar um poço. Mais difficil do que pensava foi o problema de perfurar a terra, ora aqui, ora ali, com trabalhadores pouco exercitados á sua disposiçãc; porém a persistencia foi afinal premiada com a abertura de um poço, que forneceu agua sufficiente para satisfazer ás necessidades de todos. Quanto era penoso procurar em toda a ilha e carregar ás ccstas terra fertil sufficiente para o estabelecimento de um jardim, que de desvelos assiduos no amanho das pequenas arvores e arbustos, até que tomassem pé, tornandc-se resistentes, quantos cuidados em protegel-os contra os ventos do mar, quanto trabalho na irrigação das flôres e hortaliças ! Contar tudo isto, nos roubaria muito tempo. Basta referir o resultado. Hoje a guarnição da Ascenção não precisa de importar hortaliças, podendo mesmo dar-se au luxo de collher laranjas a pecegos da ilha. A vista póde alegrar-se nos grupos verdejantes dos bosques, 
e quanto mais augmenta o seu numero, tanto maior é o exito na procura da agua, tanto mais se enchem os poços. Com isto cresce a facilidade de se augmentarem as culturas. Ascenção deixou de ser um deserto, em virtude da energia de unı soldado instruido.

Perguntamos si esses exemplos não dão direito a concluir, que os homens podem extinguir qualquer deserto? A duvida e a pusilanimidade podem arriar bandeira perante as razões que aqui apresentamos. Energia e actividade são cs primeiros requisitos absolutamente indispensaveis para dominar o deserto. Obras tão grandiosas, emprezas tão ousadas como nos tempos que correm, nunca foram planejadas, nem executadas. E săo a mesma energia e actividade verdadeiras, tanto mais obstinadas, quanto maiores forem as difficuldades, que se nos antolham, a par do encanto, que está na victoria sobre o apparentemente impossivel! E' verdade; proporções gigantescas sómente podem attingir os problemas a resolver, porque vivemos na idade de ouro das machinas a vapor, da electricidade e da mecanica. Feitos, que os ncssos antepassados qualificavam de sonhos e chimeras, hoje se executam com certeza absoluta, podendo até ser excedidos.

Por essa sujeição das forças da natureza e no progresso admiravel dos meios auxiliares mecanicos, adquirimos a certeza de que homens energicos e activos podem sujeitar, á sua vontade, o deserto.

A Natureza não distribuiu aqui luz sem sombra, acolá sombra sem luz, aqui beneficios sem trabalhos, acolá condemnação sem remedic, mas espalhou as suas dadivas por toda a parte, e onde deu com abundancia pesou bem a compensação: muita luz, muita sombra. Onde nos parecer difficil a comprehensão dessa verdade, teremos de queixar-nos da insufficiencia da nossa sciencia ou da superficialidade das nossas observações. A força creadora, que deu ao Sul as flôres esplendidas e ao Norte os fructos magnificos, que prendou com bellas flôres o feio cactus e negou-as á bella palmeira, que se descuidou da plumagem da cotovia e do rouxinol e doou com voz feia ao pavão e á ave do paraiso, que deu bellos olhos ao sapo e armou com alta intelligencia a formiga, que illuminou o mar glacial com a aurora boreal e inflammou como o arrebol os cumes das altas montanhas-essa mesma força creadora lembruu-se tambem do deserto, porque em parte alguma as côres brilham e faiscam tanto como nelle; em seu seio estão guardados os mais ricos thesouros mineraes e não raras vezes com incrivel fertilidade - tomada esta palavra em seu sentido vulgar, - crescem plantas, que sob fórmas singelas ou mesmo repulsivas escondem uma utilidade mais ou menos estimavel. Descobril-a e exploral-a, é um problema remunerador para homens activos.

A humidade está destinada a transformar, nos dias vindouros, grandes terrenos desertos em paraizos cobertos de fiòres. Quando houver agua nesses logares, será relativamente facil tornar productivo o deserto para um numero maior ou menor de novas plantas cultivadas, e comprehensivel e descul. pavel é que as emprezas venham a utilizar primeiro esse methodo conhecido desde a antiguidade e ainda em uso. Duvidas de maior peso, porém, se apresentarão, exigindo prudencia circumspecta, quando se tratar de equilibrar as primeiras despezas de um estabelecimento com o calculo da renda. Precisará o terreno ser nivelado para o fiın da irrigação? Não será necessario para o 
estabelecimento e a funcção das obras de irrigação o gasto de un capital, cujos jurcs elevados absorverão a renda liquida? Si a resposta fôr desfavoravel á cultura planejada, então provado está que unna concurrencia victoriosa com collegas, que trabalham sob condições mais favoraveis, não é possivel; a realização de semelhante empreza, seria um suicidio economico, comparavel áquelle que commettem us lavradores allemães nas montanhas, pensando cultivar searas mesquinhas de trigo para concorrer com os resultarlos das ricas colheitas nas planicies. Em nossos dias a concorrencia não tem mais limitação local e deve ser levada em conta, mesmo no caso do producto servir ao proprio consumo.

Não podend ser realizadas as obras de irrigação por causa das despezas elevadas ou tendo-se de supportar a falta d'agua como facto irreparavel, trate-se, então de escolher, para a cultura, as plantas que possam viver no deserto e que, portanto, encontrem ali as condições de crescimento sem o auxilio diss homens. E nisto está o futuro propriamente dito da exploração do deserto, assim como da de outros terrencs estereis. Empregar tempo, força e capital para tornar possivel a cultura de plantas uteis de exito problematico, não póde, nem deve ser o fim da agricultura, por conduzir a uma situação economica instavel e precaria; mas, ao contrario devem-se procurar plantas para as condições dadas, que sem preparos extraordinaricis sejam cultivaveis e encontrem prosperidade segura. Desenvolvendo esse systema, podemos nutrir a esperança de cultivar até em rocha núa. As lichenaceas tinturáréas, tão estimadas, não vivem em rochedo nú? Para sermos melhor comprehendidos, vamos citar alguns exemplos. Sobre o lago Michigan floresce Kalamazoo, denominada chistosamente a cidade dos aipos, porque sua existencia depende da cultura deste sob todas as fúrmas. Ainda ha poucos annos havia, no mesmo logar, um pantano formado pelas ondas do lago, terreno de alluvião que visivelmente encerrava nciavel fertilidade, porém que não foi cubiçado por pessôa alguma, por sua drenagem consumir sommas, cujos juros talvez não seriam pagos pela renda. A um hollandês residente na visinhança coube desatar esse nó gordio. Procurou uma planta que encontrasse neste sólo as ccndições de crescimento e que, portanto, nelle pudesse ser cultivada sem grande difficuldade e a descobriu no aipo.

A unica difficuldade, que havia, removeu-a, calçando o seu cavallo com sapatos em fórma de pratos, para impedil-o de atolar-se no pantano, pratica essa que até hoje tem sido conservada.

Aquelle homem emprehendedor viu excedidas as suas esperanças mais usadas. Não sómente as colheitas foram abundantissimas, como tambem de qualidade tão excellente, que lhe grangearam rapidamente fama em toda a America do Norte. O aipo de Kalamazoo ainda não foi excedido na qualidade; o seı nome é uma recommendação. Não é de admirar, pois, que encontrasse imitadores. Em pouco tempo havia nesse pantano uma série de campos de aipo, uns ao pé dos outros, formando-se uma cidade, que em 1885 já exportava aipos no valor de um milhão de marcos.

Em um dos Estados mais antigos da União Norte-Americana, Nova-Jersey, acha-se una região só colonizada modernamente, embora esteja proxima da costa atlantica, por unde já ha 50 annos passa a corrente de immigrantes. 
O aspecto dessas terrras tambem não era convidativo: areia, saibro, pedras, arbustos rachiticos. Não seria loucura arroteal-o, havendo o sólo fertilissimo do oéste á espera do lavrador? Mas essa regiãci occultava sob aspecto repugnante um favor inestimavel da natureza: o sólo e o clima eram proprios por excellencia para a cultura de pecegos e fructeiras arbustivas, como as groselheiras. Logo que isso foi reconhecido, acabou-se o deserto. Alli florescem hoje bosques de pecegueiros, framboezas e airellas. A população goza de bem-estar invejavel e, todavia, colhe sómente os fructos, comprando os alimentos na visinhança.

A ferro-via nacional do Mexico atravessa terrenos montanhosos, cujos habitantes outr'ora lutavam frequentemente com a fome. Nessa região solitaria eram obrigados a produzir o pão do dia, e o milho era constantemente ameaçado pela secca, fornecendo nu melhor caso resultados modestos, por serem o sólo e o clima poucos proprios á sua cultura. Desde que foi aberta ao trafego a estrada de ferro, os habitantes, á margem della, nas montanhas do Mexico, compram milho no Texas e o pagam com os pruductos da istle (Bromelia sylvestris). De anno para anno essa permuta adquire maicres proporções e maior firmeza; as vantagens estão patentes á intelligencia mais acanhada. Nas montanhas mexicanas, comparaveis ao deserto, a istle tem sua patria; alli prospéra e dá colheitas certas. Cultivando-a nessa região por toda a parte e vendendo a sua estimada fibra para comprar o milho necessario nas regiões onde é produzido, seguro e barato, em condições mais favoraveis, os habitantes não sómente estão a salvo da carestia, como tambem colhem ainda um excesso pela renda liquida.

Involuntariamente fazemos u1ma comparação com Yucatão que explora muito bem a cultura da agave-sisal, por lhe darem os cereaes e leguminisas colheitas mesquinhas e incertas. Assim é que essa peninsula exporta o canhamo, a agave, importando o milho e o feijão. E assim Yucatão não decahe.

Nesse systema deve-se fundar a exploração do deserto. A sua possibilidade cresce c rm o desenvolvimento progressivo da industria e da vida commercial na terra. Fibras e tanninos, cuja producção só é possivel no deserto, já são productos de primeira ordem para o commercio internacional e gozam em todos os paizes civilizados de procura crescente. Purque o deserto não ha de contribuir para o augmento das materias primas necessarias á industria ? Sua sujẹição dará tanto mais proventos, quanto mais se ramificar a rêde da viação, e, seguindo o exemplo das industrias mecanicas, se transformar toda a cuitura do sólo pela divisão do trabalho. E' imprudente fechar C.S olhos' ante esta transformação inevitavel, e mais importante ainda será querer lutar contra ella. $\mathrm{Na}$ rapida adaptação ás condições mudadas, não sómente o negociante e o fabricante, como tambem o agricultor excessivamente conservador, em seu proprio prejuizo, deverão procurar a salvação, e, ensinando-lhes a estatistica, que no decennio de 1840-50 foram construidos 28.740 kilometros de ferro-vias, no de $1850-60$. 64.860. no de I860-70, 94.860, na decada de I870-80. I48.245 e mais, que no correr dos ultimos 40 annnos, quintuplicou a frota dos navios mercantes, tudo isso lhes faz um appello séric á actividade. $O$ que ha a objectar contra a divisão do trabalho na agricultura para defender o antigo systema de exploração, sabemos muito bem; porém, a todas as theorias sagazmente urdidas oppomos esse facto irrefutavel. Em todas as nossas 
peregrinação na patria e nos paizes extrangeiros, observamos attentamente que sómente tiveram exito os agricultores que se especializaram.

Isto poderá servir de animação para os corajosos, que querem imprimir ao deserto o cunho da sua intelligencia e actividade. A elles entregamos a seguinte lista de plantas, que não consideramos completa, mas servirá apenas de base para explorar o deserto.

\section{CACTO GIGANTE (CEREUS GIGANTEUS)}

Nas encostas estereis das montanhas dc noroeste do Mexico, assim como nos desertos alcalinos de Arizona, crescem isolados ou em grupos muito distantes uns dos outros, os caules do cacto gigante, de seis até I 5 metros de altura e o,6 até I,3m. de espessura que, em virtude de se parecerem com columnas dos antigos edificics, poderiam ser chamados cactos monumentaes.

Em uma columna profundamente canelada, com poucos galhos curtos na proximidade do apice, levanta-se esse habitante do deserto, com uma apparição que á noite produz impressão sinistra, principalmente á pallida luz da lua. Os indios e os pastores mexicanos se alegram, vendo um cacto gigante, e o viajor se rejubilará tambem ao atravessar esses desertos sem agua, por ser essa columna viva dadiva estimavel da natureza. Quando o caule está lenhificado serve aos indios para fabricar arcos e flexas, e de combustivel aos pastores mexicanos.

Mais importante, porém, é o cacto gigante pela producção de fructos pyriformes, verde-amerellados, cobertos de poucos espinhos, muito distantes uns dos outros, que cahem quando a maturação é completa. Os fructos nascem na vizinhança do apice, d'onde são tirados com varas curvadas. O interior dos fructos tem uma bella apparencia vermelha, seductcra. A casca tem fibras molles e é succulenta e doce, a polpa é saborosa, contendo muitas sementes pequenas, pretas, que tambem se comem, sendo, porém, indigestas, quando não são bem mastigadas. Esses fructos lembram figos, porém são muito mais succulentos; para os indios são uma gulodice, com que se satisfazem como unico alimento, emquanto podem obtel-o. A's vezes seccam a polpa na palhinha de milho, a qual atam em ambos os extremos, expond $d$-a ao sol. Isso fazem quando pretendem a sua conservação por mais tempo, porque, para canserval-a por pouco tempo, basta encher potes de barro com a polpa nova e fechal-os hermeticamente. Os indios mansos e industriosos, chamados Papajos, expremem a polpa em uma bolsa feita de panno e vendem um xarcpe limpido e de côr castanho-clara, assim obtido, por dous a cinco dollars o gallão ( 4.5 litros) aos habitantes brancos da Arizona. Os seus vizinhos, os indios Pimas, que são muito indolentes, fabricam da polpa uma bebida alcoolica, da cór de ambar, que tem o sabor de cerveja acida, estragada, deixando-a misturada com agua a fermentar ao sol. Logo que a fermentação está completa, começam as festas, que realmente não são outra cousa sinão orgias.

Agora perguntamos, si não vale a pena cultivar este cactc util em outras regiões desertas de ambos os hemispherios, para incluil-o entre as plantas cultivadas em toda a parte ? Que ha de ridiculo no projecto de estabelecer bosques de cactos e de cuidar dos amanhos para produzir fructos? Não se póde negar 
a probabilidade do cacto gigante ser aperfeiçoadc como arvore fructifeva por uma cultura continua e racional, fazendo-se os respectivos amanhos. Suppondo, mesmo, que a producção de fructos em maior escala não fosse remuneradora, a plantação do cacto gigante trará, por certo, em virtude da producção de fructos e de combustivel, a vantagem de tornar habitaveis regiões consideradas aridas e a cujo sólo os caules do cacto gigante em putrefacção podem levar a desejada fertilidade, tornando possivel a agricultura.

\section{CACTO DE THURBER (CEREUS THURBERI)}

Os mexicanos chamam essa especie de cacto, pitayo, o qual com o diametro de I5 até $20 \mathrm{~cm}$. alcança a altura de 5.5 a $6 \mathrm{~m}$. E' sómente enccntrado ao sul da costa occidental do Mexico. Os fructos têm a fórma e o tamanho de um ovo de gallinha e estão eriçados de espinhos compridos, pretos, muito juntos. Logo que amadurecem, o que se reconhe pela sua côr avermelhada, os espinhos cahem, abrem-se as cascas, deixando vêr uma polpa rica, succulenta, com sementes pequenas, pretas. Os mexicanos pretendem que a sua polpa é mais sabcrosa que a do cacto gigante, e, como para demonstral-o praticamente, consomem grandes quantidades. Chegaram elles ao ponto de cultivar o pitayo, espalhando a semente em qualquer logar e abandonando-a á acção da natureza.

Mergulhando os fructos na agua, a semente facilmente se separa da polpa; secca e triturada fórma um alimento digerivel. Da polpa se póde preparar um bom xarope.

Existe ainda o cacto-candelabro (Cereus quicsco), que cresce na America tropical, nas encostas rochosas; os seus fructos doces e mucilaginosos são muito apreciados.

\section{ECHINOCACTO (ECHINOCACTUS WISLIZENI)}

Bisnacha é o nome mexicano desse cacto, que adquire dimensões menores do que os precedentes, por alcançar sómente $3 \mathrm{~m}$. de altura e $0,5 \mathrm{~m}$. de diametro. A sua pclpa é acida, e raras vezes comida, porém, com as pequenas sementes pretas prepara-se uma farinha alimenticia. Os viajantes nos desertos do Mexico septentrional e na Arizona meridional, muitas vezes recorrem a esse cacto, para desalterar a sêde, porque a parte interna do caule, sendo mastigada, tem sabor acido, agradavel. Quasi todos os echinocactos em ambcs os lados do caminho, através do deserto, têm grandes buracos feitos pelos viajantes sedentos. Alguns pedaços do caule são utilizados frequentemente como panellas para cozinhar. Quando um indio em viagem quer preparar a sua comida, procura um grande echinocacto, corta um pedaço do caule de cerca de I $\mathrm{m}$. de comprido e $\mathrm{I} / 2 \mathrm{~m}$. de espessura e, cavando-o, faz delle uma pia. Nelle lança a parte molle, tirada do pedaço do cacto, a carne, as raizes ou qualquer cousa comestivel, que ainda tenha e agua sufficiente. Em seguida aquece em fogo bem acceso, o mais possivel, uma pedra apanhada no campo, e lança-a tambem na pia. Depois de esfriada a pedra é aquecida de novo, usando-se o mesmo 'processo. Isto basta em geral para 
cozinhar a comida; raramente torna-se necessario aquecer a pedra pela terceira vez.

Os indios Papajos descascam-no com os espinhos, sem cortal-o, deixando-o por alguns dias exposto ao sol; defendem depois o caule para extrair a parte interna, molle, que cortam em pedaços e cozinham no xarope preparado dos cactcrs gigantes e de Thurber. Essses pedaços seccos têm o sabor de c drão, constituindo um bom succedaneo do mesmo.

O echinocacto cresce ao sol ardente em sólo silicoso e secco; parece que não têm necessidade alguma de humidade.

\section{NOPAL (CACTUS OPUN'TIA)}

Desse genero ha cerca de I5o especies.

Opuntiatuna, segundo outros O. Engelmani ou $O$. occidentalis furnece os fructos conhecidos no Mexico pelo nome de tunas e produzidos em enormes quantidades, que em parte seccam para o consumo no inverno.

O fructc é grande, vermelho-claro, de sabor acridoce, agradavel; a casca é fina; as grandes sementes não são utilizadas. A casca é coberta de espinhos vellosos, que os indios escovam com um tufo de capim, quando querem seccar os fructos ou cozinhal-os novos, de mistura ccm carne e raizes. Os fructos verdes são cozidos, ás vezes, n'agua, durante io ou I2 horas, pelo que adquirem as propriedades da compóta de maçãs. Algumas tribus torram as partes do caule, depois de cozidas, tiram a casca ccm os espinhos, restando para comer uma massa mucilaginosa, doce e succulenta. O nopal vegeta em sólo que não possa produzir outra planta.

$\mathrm{Na}$ rocha vulcanica, núa, bastando ser fendida, no sóld silicoso e saibroso, mas esteril, vegeta o nopal vulgar que, apodrecendo, enriquece de humus esses logares desnudados, de sorte que possam produzir outros vegetaes. O nopal é um verdadeiro pioneiro da cultura. Os seus fructos são amarello-avermelhados, do tamanho de um ov r de gallinha, que em certas regiões constituem genero commercial. E' uma planta excellente para sebes.

O. camanchica $\mathcal{C}$ O. Rafinesquin, ambos oriundos de Arizona e do Mexico septentrional, fornecem fructos que os indios comem.

O. nana ou nopal anão, é parecido com o nopal commum, de menor tamanho, satisfazendo-se com pouco calor. E' de muito valor para as regiões de clima frio onde se não adapta a mór parte das especies de cactos.

\section{CAC'TO-MELÃO (MELOCAC'TUS COMMUNIS)}

E' originario da America Central; tem fórma espherica ou ovcide, com 30 até $60 \mathrm{~cm}$. de diametro, cuja superficie apresenta sulcos numerosos como o melão. As saliencias ou partes ovaes, achatadas, estão cobertas de feixes de espinhôs em series regulares. Cada feixe se compõe de cerca de cinco espinhurs grandes e de um certo numero de pequenos espinhos agudos. Nas partes ou 
membros do cacto, nascem pequenas flôres vermelhas, que produzem baguinhas da mesma côr.

Essa planta singular cresce de ordinario nos logares rochosos, onde encontra pouca ou nenhuma terra para nutrir-se. Onde se acham as substancias alimenticias? Abrindo-o, encontramos uma massa molle -e succulenta.

Como é possivel a esta planta juntar tanta exuberancia de humidade em rochas torradas pelo sol, em longos mêses sem chuva?

No tempo da secca o gado procura esses cactos, parte-os, esfergando-os com chifres e come a massa interna que é substancial.

As bagas, de sabor acidulado, agradavel, não se comem sómente na America Central, mas tambem nas Antilhas.

\section{GROSÊLHA DE BARBADOS (PEIRESKIA ACULEAT،)}

Essa especie de cacto, originaria das Antilhas, de caule redondo, de folhas espessas, achatadas, alternantes, cobertas de fortes espinhos e de flôres alvas ou amarelladas, produz fructos de agradavel sabor, os quaes têm effeito emolliente. A planta é cultivada frequentemente em sólo silicoso e secco.

Aos cactos precedentes ainda se póden incluir os apropriados para a forra. gem, cujo numero é consideravel.

Por escarneo costumam denominar o Mexico "o paiz dos salteadores e dos cactos", sem perceberem que elle possue nestes, que são considerados com tanto desprezo, fonte natural de bem estar muito estimavel. Sem lembrarmos a producção dos fructos, apontaremos o facto de que em regiões extensas, a industria pastoril depende inteiramente daquelles fructos.

Isso é ignorado pelos escriptcres viajantes, que frequentam grandes vias de conmunicação e os melhores hoteis. Mas, quem percorrer o paiz em todos os sentidos, procurando conhecer a sua natureza e o povo que o habita, conversando opportunamente com um criador de gado, não levará muito tempo em reconhecer o valor em que são tidos os cactos no Mexico. Onde haviam de procurar a forragem para as ovelhas no longo periodo da secca ? Para um criador mexicano o pasto não tem valor, quando não produz cactos em abundancia, julgando elle ser o mais precioso da especie o nopal. Encolhe com desprezo os hombros, vendo um pasto hervoso e florescente, mas sem o cacto.

O pastor de ovelhas traz sempre um facão compriclo ao lado; com o qual, precedendo o rebanho, corta um pedaço de cada cacto no pasto, para offerecer um ponto de ataque ás ovelhas. Estas comem toda a planta com os espinhos. Esfomeadas, não esperam pelo auxilio do pastor: comem sem mais nem menos.

Emquanto as ovelhas se nutrem quasi que de cactos, não carecem de desalterar-se no bebedouro, nem mesmo nos mêses mais calidos, e isso é uma vantagem inestimavel em um paiz pobre de aguas.

$\mathrm{Na}$ parte noroeste do Mexico, nomeadamente no Estado de Sonora, as condições do clima, sólo e viação são taes, que a industria pastoril é o unico ramo lucrativo da agricultura e por isso constitue a exploração exclusiva nas grandes fazendas. Tão secco é o clima, tãc pobre de gramineas é o sólo em 
grandes extensões de terreno, que as manadas, sem os numerosos cactos, não poderiam viver. Criam de preferencia o gado vaccum e só pequeno numero de cavallar e muar. A criação de ovelhas nesta parte do Mexico é muito menor do que nos Estados Centraes e Orientaes.

O gado bovino, cavallar e muar não póde, por uma razão obvia, comer os cactos como as ovelhas, atacando-os no ponto offerecido pelo córte du pasior; para isso queimam os espinhos, da mesma maneira que o fazem ao porco ou ganso depennado. Vimos vaccas e cavallos em redor do fogo do pastor, esperando pacientemente que thes fossem lançados pedaços de cacto, queimados, que comiam com prazer.

Em Sonora os cactos possuem tal importancia, que as grandes fazendas são avaliadas segundo a quantidade de taes plantas nos terrenos. Perante esse facto medem-se os conhecimentos economicos e a actividade dos mexicanos, que esperam só da natureza, que cuide da multiplicação dos cactos. Si fossem mais circumspectos, calculadores e animados da vontade de explorar energicamente os dons que a natureza põe a seu alcance, a exemplo dos seus vizinhos do Norte, estabeleceriam e manteriam methodicamente pastos de cactos, para multiplicar o gado e protegel-o contra a fome e a sêde.

Ainda que nada façam neste sentido, é raro ouvir fallar da falta de forragem em Sonora e nunca a fome nas seccas causa tanta mortandade, como na Australia e Africa meridional. Não estará aqui uma indicação para os criadores dessas regiões, si quizerem aprender o modo de preservar o gado da morte ?

O nopal está introduzido na Queenslandia (Australia) e na Colonia do Cabo porém, alli sómente serve para sebes e para produzir fructos.

$\mathrm{E}^{\prime}$ ' curioso vêr como os criadores de todos os paizes, quando longe das regiões de civilização, se deixam levar pela incuria que caracteriza c nomade genuino. Embora a secca destrúa as suas manadas, continuarão ccm a antiga exploração extensiva, rotineira, por abandonarem tudo á natureza e ao acaso, esperando sempre que a secca não volte semelhante á ultima, ou exclamando, nesse caso, que seria melhor o abandono, de todc, da industria pastoril.

A propagação de todas as especies de cactos póde realizar-se pela plantação de sementes cu de estacas e, segundo qualquer um desses methodos, executa-se facilmente. A plantação effectúa-se durante a estação chuvosa em sólo secco e, juntando-se-lhe alguma caliça ou cal queimada, estimúla extraordinariamente a vegetação dos cactos.

Quem procurar, investigando, plantas uteis do deserto, alcança melhor o seu fim, perguntando aos povos selvagens por suas fontes de nutrição. Lembrando-nos disso, procuramos pesquizar quaes as plantas em que os indios norte-americanos descobriram propriedades preciosas, escolhendo dentre ellas as que pudessem corresponder á intenção que tinhamos em vista com esta exposição.

\section{RAIZ-BISCOITO (PENCEDANUM AMBIGUUM)}

Konseroot é outro nome inglès dessa planta ambellifera, originaria da parte meridional das Mcntanhas Rcchosas e da montanha Wabach; cresce nas encostas de montes tão estereis que nem mesquinho capim produzem. No mês de maio, 
tempo da florescencia, cavam-se as raizes, que depois de afastadas as cascas, são compostas de uma massa feculenta, granulosa, que a vista exercitada reconbecé immediatamente. As cascas dessas raizes são compostas de feixes fibro-vasculares, os quaes encerram uma farinha feculenta. A casca é semelhante a um cartucho de farinha, sendo, portanto, superfluo qualquer preparo. Essa farinha conserva-se durante alguns mêses, é muito alva e possue ligeiro sabor de aipo. Muitas vezes os indios fazem della bolcs ovaes, achatados, com furos no meio, para pendural-os na sella.

\section{RAIZ-PÃO (PSORALEA ESCULENTA)}

Essa planta cresce nos logares seccos dos esteppes norte-americanos e no Mexico. E' uma papilionacea, da ordem das leguminosas, que' os francêses chamam picquotiane. As suas raizes, do tamanho de um ovo de gallinha, possuem casca espessa, coriacea, que encerra uma massa feculenta, delicada. A ultima facilmente se tritura, sendo composta pela maior parte de fecula. Tem um sabor adocicado, agradavel, que lembra o da beterraba. Algumas tribus sacrificam as raizes ao "grande espirito".

\section{SAGÚ-BRAVO (CALOCHORTUS LUTEUS)}

A raiz dessa planta, oriunda da bacia deserta de Utah, alcança sómente o tamanho de uma nóz, mas é muito saborosa. Os filhos dos indios apreciam-na ccmo si fosse algum doce. Quando os Mormões estabeleceram naquella região sua nova residencia, essas raizes formaram no primeiro anno uma parte importante de sua nutrição. O que foi o manná no deserto para os judeus emigrantes para Canaan, fơ o sagú-bravo para os Mormões á procura da "terra da promissão".

\section{CANNA (CANNASSIA ESCULENTA)}

A canna não é rigorosamente uma planta do deserto, por sómente crescer ncs logares humidos, embora rochosos, dos esteppes da parte occidental da America do Norte. Mencionamo-la aqui por nos parecer propria para ser cultivada nos esteppes, savanas, pampas, campos, isto é, nos terrenos cobertos de capim das diversas regiões da nossa terra.

Não se póde objectar que os norte-americanos teriam considerado a canna, ha muito, ccmo planta util, si valesse a pena cultival-a. Ha quanto tempo cultivam as amoreiras silvestres? Porque, ha seculos, julgaram essas plantas indignas de serem cultivadas ? Esses exemplos, que facilmente poderiamos multiplicar, provam que não é razão plausivel deixar de cultivar uma planta, porque ella tem sido deixada de parte, continuando no estado silvestre.

A raiz da canna tem a fórma da cebola e o tamanho da nóz. Lembramos que as batatas bravas, chamadas inglêsas, que foram descobertas na Arizona, tambem não eram maicres, o que demonstra qual o resultado da cultura continua. A haste e a flòr da canna lembram vivamente o cyano. 
As raizes da canna são muito estimadas pelos indios, e por sua causa fizeram em Idaho uma guerra sanguinolenta, ainda muito lembrada, chamada a guerra da canna. Porque o gado dos colonos destruia essas plantas necessarias á alimentação delles, os indios romperam lucta. Tambem os brancos apreciam as raizes da canna, e muitos lavradores mandam os filhos colher em junho e julho, tempo da safra, provisões para cozinha. O sabor das raizes é semelhante ao da batata, porém mais doce; a quantidade de assucar que contém deve ser consideravel, porque, pilada e cosida na agua, fornece um bom xarope.

\section{YAMPAH (ANETHUM GRAVEOLENS)} lifera.

O endro, anetho, vulgarmente chamado funcho-bastardo é uma umbe-

A raiz fusiforme dessa planta é considerada o melhor alimento do reino vegetal pelos indios "chochones" e "serpentes"; é genero commercial entre as tribus do noroéste. Os habitantes brancos dessas regiões utilizam a semente como tempero na comida. O yampah cresce nos logares baixos dos desertos, nas montanhas de Utah, Idaho e Montana. O mesmo nome botanico tem o endro cultivado nas hortas da Allemanha e que cresce silvestre na Europa meridional. E’, porém, duvidoso que a especie americana seja identica á européa.

\section{EDOSMIA MONTANA}

Os indios colhem as raizes desta planta, as quaes têm o comprimento de um dedo. Cresce nas encostas desertas das montanhas do Oregon oriental. Os mesmos indias cozinham as raizes como batatas. O sabor é muito agradavel, semelhante ao crême.

\section{HELASCIADIUM CALIFORNICUM}

Os indios do Oregon consideram as raizes dessa planta, que crescem nas rochas vulcanicas, cobertas de muito pouca terra, como petisco de primeira qualidade, e a gente branca, que teve occasião de saboreal-as, qualificou-as de excellentes, doces e semelhantes ao crême. E' uma umbellifera de raiz preta, que se parte com facilidade. quando cosida, deixando ver o conteúdo feculento e alvo.

\section{LEIVISIA BRANCA (LEIVISIA REDIVIVA)}

Essa planta é encontrada nos logares desertos das montanhas da California. is suas grandes raizes fusiformes são colhidas pelos indios e sêccas para a provisão do inverno; julgam-nas muito nutritivas; facto que poderá ser esclarecido pela analyse chimica, que ainda não foi feita. 


\section{PAU-FERRO (OLNEYA TESOTA)}

Essa arvore cresce nos logares rochosos, desertos, das regiões pobres de agua, na parte noroéste do Mexico e na Arizona. As sementes castanhas, côr de mogno, têm a fórma e o tamanho de ervilhas e, como estas, são legumes. Os indios comem-n'as cruas ou torradas; desta maneira têm o sabor de amendoim. A madeira do tronco é bom combustivel e presta-se para obras. Em virtude dessa propriedade, a arvure merece consideração, quando se tratar de utilizar o deserto pela silvicultura.

\section{PINHEIRO DE NOZES (PINUS EDULIS)}

Nas encostas rochosas, sêccas, dos desertos, nas montanhas do Novo Mexico e das regiões limitrophes de Arizona e Mexico, cresce esse pinheiro até na altitute de 8Io m., alcançando, sómente sob condições favoraveis, a altura de nove metros e possuindo uma conformação de ramos que lembra a macieira. As sementes têm o tamanho de feijão de corda e se compõem de um nucleo muito oleifero, dentro de uma casca fina e quebradiça. Esses nucleos têm sabor doce, agradavel, que pela torrefacção se torna melhor, servindo ás vezes para extracção de oleo; colhem as sementes em quantidade, e do excesso é consumida uma parte e a outra fórma um artigo bem notavel do conmercio local. A madeira é leve e molle, mas muito resistente, mesmo em contacto com a terra; serve principalmente para preparar carvão vegetal.

Lembramos que algumas especies do genero pinheiro (Pinus) são chamadas pinheiros de nozes. A pinus edulis, de que tratamos, chamam "piñon" no Mexico, de onde é originaria.

A remessa das sementes se fará melhor dentro dos pinhões, porque seccando-se os ultimos ao sol, segundo o processo usual, até que os pinhões se abram, o oleo das sementes torna-se rançoso em pouco tempo, o que prejudica a força germinativa.

\section{CEREJEIRA ANÃ (PRUNUS PUMILA)}

Essa especie interessante do genero Prunus é apenas um arbusto de 0.6 até I. $8 \mathrm{~m}$. de altura. O fructo doce, carmezim, é um pouco maior que o abrunho; comen-no em qualquer estado. No territorio dos indios e nas partes limitrophes do Texas cresce nos logares silicosos e seccos. Para lá se dirigem de toda a parte, os indios, em tempo de colheita, para juntar suas provisões.

Outros botanicos classificam-no no genero Cerasus (C. pumila); elle, portanto, será parente proximo de Cerasus prostrata, arbusto minusculo. Os fructos agradaveis dessa cerejeira ( $C$. prostrata) são procurados assiduamente pelos indios das Montanhas Rochosas. Pertencem á familia das Amygdaleas, da ordem das Rosifloras. 


\section{FEIJÃO ESPIRAL (STROMBOCARPUS PUBESCENS)}

Esse arbusto baixo, ás vezes chamado mesquita espiral ou tormilla (Strobacarpus pubescens) é uma verdadeira planta do deserto, encontrada nas regiões desertas de Utah, Colorado, Arizona e Novo Mexico, isto é, nos logares baixus e silicosos. As sementes dos legumes, cosidas na agua, dão excellente comida, semelhante ao pirão de cevadinha. Os indios apreciam-no muito e os soldados da União delle se lembram agradecidos, porque nas campanhas fatigantes contra os indios, nesses desertos tristes, muitas vezes alli os protegeu contra a fome, lhes forneceu lenha e offereceu nutrição benefica nas folhas e ainda mais nas sementes a seus animaes esgotados. Todo gado come as sementes com visivel avidez, mesmo estando bem nutrido. O nome de feijão espiral provém da fórma cylindrica e helicoidal dos legumes que têm cerca de $4 \mathrm{~cm}$. de cumprimento.

\section{MESQUITO (ALGAROBIA GLANDULOSA)}

A região de distribuição geographica dessa arvore limita-se ao sul com a do feijão espiral. Ambas se confundem ás vezes; pertencem á ordem das leguminosas. O mesquito é da familia das Mimoseas. Os legumes de ambas tambem são differentes.

O mesquito, enl geral, é um arbusto mais ou menos alto, em condições favoraveis; sendo, porém, cultivado, transforma-se em arvore, que attinge a doze metros de altura. Nesse estado, com sua cópa arredondada e ramos armados de espinhos, lembra vivamente a acacia falsa (Robinia prendacacia), que tambem é uma leguminosa. O rio Colorado fórma o limite septentrional de sua distribuição geographica; o limite meridional não é conhecido, encontrando-se a especie na America Central e nos Andes até o Chile. A léste acha-se até perto do littoral do Texas, ao oéste até o Golfo de California. Dentro dessas linhas que comprehendem grandes desertos, cresce nas encostas sêccas das colinas e muitas vezes é o unico representante do reino vegetal nessas regiões. Os legumes têm I 5 até $20 \mathrm{~cm}$. de comprimento, são achatados, um pouco curvos e articulados; amadurecem em junho e encerram uma polpa acri-doce.

O mesquito é de extraordinario valor para os habitantes das partes mais estereis das regiões de sua distribuição geographica; os indios e os mestiços mexicanos, parece, não continuariam a viver alli sem essa arvore. Em vão procurariam lenha necessaria, que em muitos logares é unicamente fornecida por elle. Combustivel excellente, comparam-no ao carvão de pedra, sendo difficil encontrar materia melhor para o fabrico do carvão vegetal.

Quando os troncos têm espessura sufficiente, fornecem excellente madeira para obras de carpintaria e são muito procurados pelos marceneiros, porque o duramen apresenta côres ricas, do vermelho-amarellado até á purpurea; faz contraste vivo com o alburno de côr amarello-pallida e ambos recebem fino polimento. Nas cidades texanas, de Antonio e Brownsville executaram-se calçamentos com cubos da madeira de mesquito, que muito satisfizeram.

De maio até setembro uma resina côr de ambar escorre dos seus tronccs. tendo aspecto da gomma arabica. Dissolve-se facilmente em tres partes d'agua 
e produz uma bôa substancia collante. Chimicamente se distingue da gonma arabica, porque em solução não é precipitada pelo sub-acetato de chumbo (acetato de chumbo basico) como aquella. Quanto mais velho o tronco, quanto mais espessa e rachada a casca, tanto ma1s abundantes são as exsudações. Das feridas velhas, deixadas pelos ramos quebrados, transuda a gomma. Uma grande arvore fornece espontaneamente a colheita de cerca de 120 grammas que poderá ser elevada por incisões até o maximo de 400.

Presentemente essa resina se tornou artigo de commercio de alguma importancia, principalmente de exportação para o Mexico, onde muitos estabeleci.mentos a vendem como succedanea da gonma arabica. Avaliam annualmente entregar ao commercio 8.000 kilogrammas dessa resina.

A arvore em geral fica sobrecarregada de legumes que amadurecem em junho e julho, formando uma nutrição importante para os indios e os mestiços mexicanos, assim como para os seus cavallos e mulas. Tambem os soldados da União, nas suas campanhas, souberam apreciar o seu valor. Um official encarregado de medições declarou no relatorio ao secretario da Guerra que o exito de sua expedição teria sido impossivel sem a existencia das favas de mesquito.

Não é aconselhado offerecer aos animaes essas favas em estado sêcco, porque os pedaços das cascas lhes causam inflamações intestinaes. Os legumes verdes não têm valor, e bem maduros, devem sér colhidos e guardados em logar sêcco, inaccessivel aos insectos. Esses legumes estão tão expostos aos ataques de larvas, que os indios e mexicanos não conhecem outra defesa contra as mesmas senão tritural-os immediatamente em um pilão ou almofariz, reduzindo-os a uma farinha fina, que guardam ben fechada, até que a empregam no fabrico de um pão grosseiro. E' provavel que as larvas habitem os legumes já no começo da colheita, sendo mortas pela trituração. Assim se explica porque a farinha se conserva por mais tempo que as favas. Os indios não se importam com a presença das larvas, porque as consideram como um augmento de nutrição. Planejando-se ensaios de cultura, merece ser considerado que já se tomam medidas de precaução no logar da colheita da semente contra o apparecimento das larvas e principalmente quanto ao transporte.

A polpa e a semente dos legumes encerram $26^{\circ} 1^{\circ}$ de glucose e, além desta, albuminoides, gomma, assim como pequenas quantidades de oleo e mineraes. Não é sem razão que se comparam os legumes do mesquito aos dos tamarindeiros. Ambas as plantas são leguminosas. Tambem os legumes do mesquito servem como os do tamarindo para preparar uma bebida nutriente e refrigerante, misturando-os, triturados grosseiramente, com agua. Os mexicanos procedem de outro modo, quando preparam o seu atole, de sabor agradavel. Primeiro cosinham os legumes na agua, depois substituem a agua quente pela fria, esmagam-n'os nella e algum tempo depois côam o liquido. Deitando-se agua na farinha dos legumes, facilmente fermenta, do que resulta uma bebida fracamente alcoolica.

Não devemos olvidar que o mesquito se presta muito bem para formar sébes e tapumes de protecção. Nas regiões pobres da zona subtropical póde prestar serviços estimaveis, assim aproveitado. 
O director dos jardins de Kew, dr. Hooker, pesquizador infatigavel do reino vegetal, tambem chamou a attenção para o mesquito e tentou a sua introducção em algumas colonias britannicas.

\section{SOTOL (DASYLIRION TEXANUN)}

E’ planta perenne, pertencente á familia das Liliaceas; tem folhas compridas e verdes, e produz uma haste floral, espessa, de tres metros de altura, de folhas compridas e verdes, uma vez em tres até quatro annos. No Texas occidental, no Novo Mexico meridional e ao norte do Estado mexicano de Chilmalma é denominada sotol. Nessa região geographica cobre extensos terrenos de encostas pedregosas, estereis, de collinas, principalmente nas altitudes de I5O até 200 metros. As folhas de 0.90 até I.2 m. estreitas, de côr verde- clara, nascem de um caule de 0.60 até $1.5 \mathrm{~m}$. de altura, de sorte que, visto de alguma distancia, o terreng coberto com esse vegetal lembra um campo cultivado de repolhos.

Os pastores extrahem das folhas uma fibra grosseira, de que fabricam esteiras e cordas. Valor commercial nunca terá, porque as suas cellulas são curtas. O valor proprio do sotol reside no caule, que serve principalmente para forragem de ovelha, mas tambem para a nutrição do homem e para o fabrico de alcool. O pastor que leva o seu rebanho ao pasto de sotol, precede-o armado com facão comprido e fende os caules, cuja massa molle e summarenta é comida ávidamente pelas ovelhas. Depois de acostumadas a essa forragem, as ovelhas sabem servir-se a si mesmas, não esperam pelo pastor, para arrancar as folhas, e atacam o caule, roendo-o. Essa forragem, dizem, engorda, o que parece provavel, por conter muito assucar. Além disso mitiga tanto a sêde, que é superfluo levar as ovelhas ao bebedouro. Durante os mêses quentes o sotol é considerado a forragem mais preciosa para ovelhas, e é fóra de duvida que a nutrição dos grandes rebanhos não seria possivel sem a sua existencia.

Os mexicanos comem os seus caules cosidos ou assados. O ultimo preparo é o mais appetecido e dá-se da seguinte maneira: cavam um buraco, em que possam caber de seis a oito caules e aquecem-no ben. Depois, retiram a lenha que não se queimou, deixando apenas as brazas, sobre as quaes lançam os caules, que cobrem com terra. Dez a doze horas depois estão assadas; então, apresentam um aspecto castanho, succulento e têm sabor adocicado.

Depolis desse processo de assar, os caules podem ser utilizados para a distillação. Essa industria desenvolveu-se extraordinariamente nos tempos modernos, nas regiões mexicanas, principalmente em virtude da benevolencia com que o fisco auxilia esses fabricantes de bebida alcoolica. Ao producto chamam mescal de sotol; é quasi incolor, tem um sabor que lembra o whisky escossês e um odor peculiar, penetrante. Essa aguardente forte, inebriante, é muito estimada nas baixas classes do povc mexicano.

O Departamento de Agricultura em Washington, que recebeu uma partida de sotol para mandar proceder á analyse chimica, verificou que o peso do caule foi de 2.954 grammas e o da massa interna. molle, de 920 grammas ou $3 \mathrm{I}^{\circ} \mathrm{o}^{\circ}$ do caule todo. Dessa massa se expremeu $3^{8.3^{\circ}} /^{\circ}$ de caldo, que possuia o pes especifico de I.I4O4 e continha $\left.32^{\circ}\right|^{\circ}$ de substancias solidas. 
O envolucro duro do caule continha $\left.16.4^{\circ}\right|^{\circ}$ de caldo com $\left.\mathrm{I} \mathrm{S}^{\circ}\right|^{\circ}$ de assucar approximadamente. A massa interna continha $\left.10.5^{\circ}\right|^{\circ}$ de assucar e, calculado para todo o caule, havia $\left.\mathrm{I} 5.5^{\circ}\right|^{\circ}$ dessa substancia immediata.

Sómente fizeram analyse exacta com a massa interna. Esta encerrava $65^{\circ}{ }^{\circ}$ de agua e depois de secca ao ar verificou-se a seguinte composição:

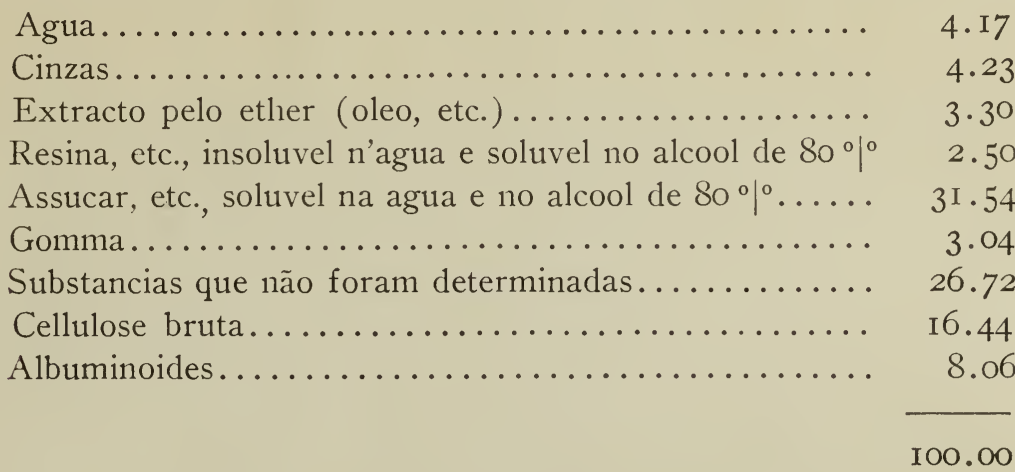

\section{AZEDEIRA (RUMEX HYMENOSEPALUS)}

"Tanners Dock of Texas" é um outro nome dessa planta, que indica claramente a sua utilidade: é um cortim. Até bem pouco sómente foi elle empregado pelos cortidores de Texas; modernamente, porém, achou apreciação mais geral.

Essa azedeira, uma Polygomea (da ordem das Fagopyrinas), se encontra em Novo-Mexico, Arizona, California Meridional e nos districtos limitrophes do Mexico, a saber: no sólo silicoso, embora profundo, todavia imprestavel para outras culturas, cobrindo-o muitas vezes inteiramente.

Os tuberculos semelhantes a batatas formam a parte mais preciosa da planta; sómente elles contém tannino, tem Io até $20 \mathrm{~cm}$. de comprimento e de dous a cinco $\mathrm{cm}$. de espessura. A casca de côr castanho-escura tem ranhuras, a massa interna é castanho-avermelhada, escura e tem cheiro de garança. No estado pulverizado tem uma côr castanho-avermelhada, clara. Em estado bem novo a casca é liza e a massa interna de côr amarella de limão. O sabor é muito adstringente, o que revela o tannino.

O prof. Hilgard, da Universidade da California, examinou os tuberculos da azedeira, obtendo os seguintes resultados:

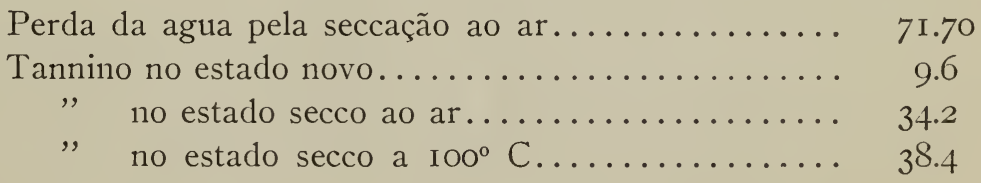

O Departamento da Agricultura em Washington, que examinou tambem os tuberculos de azedeira, aliás, com pouca exactidão, diz ter achado $18 \%$ de fecula, $\left.\$ .2 \mathrm{I}^{\circ}\right|^{\circ}$ de albuminoides, e outras substancias, sobre as quaes nada informa, abstrahindo do tannino, que chamou rheo-tannino. 
Considerando-se a necessidade hoje manifesta de cortins, a azedeira merece tanto maior attenção para utilizar os desertos arenosos, porque dentro de um anno fornece productos e exige pequenas despezas.

\section{ALGAROBO (BALSAMO CARPON BREVIFOLIUM OU PROSOPISHORRIDA)}

Nos desertos do Perú, nas depressões, que acumulam alguma humidade das chuvas escassas, cresce uma arvore baixa de ramos tortuosos, a que dão o nome de algarobo e algarobilla. As folhas offerecem uma forragem bem proveitosa ao gado vaccum e cavallar, quando atravessa os desertos. A utilidade propriamente dita dessa arvore está na producção de legumes, que contêm de 50 a $60{ }^{\circ}{ }^{\circ}$ de tannino, além de cerca de $20^{\circ} j^{\circ}$ de gomma e alguns resina. (Parece, pois, ser uma Leguminosa, da familia das Caesalpineas). Essas favas se cclhem para servir ao fabrico da tinta, para o que é excellente, por conter, além de tannino, quantidade consideravel de gomma.

\section{KUSU (PUERARIA THUMBERGIANA)}

Auctores francêses chamaram ha pouco a attenção para este vegetal japonês, preconizando-o para ensaios de cultura nas colonias francêsas. As raizes se compõem pela maior parte de fecula, as folhas novas servem para forragem, sendo bem conhecidas, e fornecem uma fibra, de que se fabricam artigos de cordoaria.

O kusu cresce no Japão no sólo mais esteril, em que nenhuma outra planta vegeta, attingindo em um anno a altura de 3.5 até $6 \mathrm{~m}$. Como condição de crescimento exige notavel quantidade de calor. A propagação póde-se realizar por sementes e renovos.

\section{ZACHUN (BALANITES AEGYPTIACA)}

Uma pequena arvore espinhosa, de aspecto feio, da familia das Zygophylleas e da ordem das Terebinthinaceas é chamada Zachun pelos arabes. As pequenas flôres branco-esverdeadas produzem fructos do tamanho de uma nóz, que no estado maduro têm côr verde. Nos desertos da Asia Ocidental encontra-se essa arvore com bastante frequencia, assim como no Egypto, na Africa Septentrional, mesmo na Africa Occidental, mas sempre nos desertos silicosos. Cresce na vizinhança do Mar Morto e se espalhou para o leste até as Indias. Com resistencia incrivel defende-se contra as tempestades que levantam ondas de areia no deserto.

Dos fructos os arabes extrahem um oleo, a que attribuem propriedades curativas e que, talvez, ainda possa ser empregado em outros fins. Da venda desse oleo aos viajantes, particularmente aos peregrinos, os arabes, que habitam a Palestina, fazem negocio lucrativo. Da madeira dura do zachun os torneadores de Jerusalém fabricam diversos objectos, principalmente bengalas. 


\section{MELÃO-ZAMA}

No deserto de Calahari, quando cahem os primeiros aguaceiros da curta estação chuvosa, nasce um melão chamado zama pelos Namaquãs, o qual com os seus estôlhos cobre grandes superficies da areia. Os ultimos deitam flores amarellas, que produzem fructos do tamanho de um ovo de avestruz, constituindo as fontes vegetaes do deserto para os "Bosquemanos" e Beduinos errantes, e mesmo para os negociantes brancos, porque são muito succulentos. Si bem que o seu valor nutritivo seja insignificante, merece, todavia, consideração pelos recursos que fornece aos que atravessam o deserto.

Ao norte do Calahari (na Africa meridional) cresce um melão adocicado, introduzido pelos Betchuanos, como estes pretendem, e que chamam mangotam. Serve para mitigar a fome e a sêde. Esses melões, cultivados regularmente, não fariam habitavel um deserto?

\section{EUCALYPTOS AUSTRALIANOS}

Das especies do genero Eucalyptus (da familia das Myrtaceas) o celebre conhecedor do reino vegetal, australiano, o Barão von Müller, recommendou para cultura nas regiões desertas o eucalypto assucarado, (Eucalyptus corynocalyx), cujo tronco de um diametro de 1.5 até $\mathrm{r} .8 \mathrm{~m}$., alcança $36 \mathrm{~m}$. de altura. O gado vaccum e o lanigero procuram avidamente a sua folhagem adocicada, comem todas as folhas que podem alcançar, c que não fazem com nenhuma arvore desse genero. A madeira é pesada, densa, dura e resistente, nomeadamente na terra e se emprega para obras de construç̧ão, de carpintaria e torneiro, na fabricação de dormentes e postes de telegraphos. O eucalypto assucarado cresce em sólo secco e pedregoso e sóbe até altitudes consideraveis nas montanhas; foi 11.troduzido, com exito, no sertão secco da Argelia.

Dentre os eucalyptos uteis, capazes de resistir ás sêccas prolongadas', assim como ao calor extraordinario das regiões desertas, ainda mencionaremos, como productores de madeira em pouco tempo, porque crescem rapidamente, as seguintes especies: Eucalyptus polyanthena, E. bicolor, E. salubris, E. ochrophloia, E. salmonophloia e E. mirotheca. Ainda que o melhor de todos os eucalyptos, o vermelho (E. rostrata) tambem possa supportar uma temperatura extraordinaria e sêcca, comtudo sómente se encontra nos logares onde o sub-sólo argiloso é sémpre um tanto humido, e tem seu habitat natural nos oasis e ás margens dos rios, embora seus leitos estejam temporariamente sêccos.

Todas as especies mencionadas fornecem bôa madeira para construcções e outras obras, e tambem se pódem utilizar vantajosamente para produzir carvão vegetal e alcatrão, assim como no preparo de vinagre. Das folhas póde-se extrahir oleo que serve para lacres e perfumaria.

Tratando-se de produzir rapidamente só a lenha para combustivel no deserto, póde-se cultivar tambem o E. Pachyphylla. Essa especie antes cresce como arbusto do que como arvore; é encontrada nos desertos da Australia Central, onde 
atravessa incolume as sêccas mais rigorosas. O calor que supportam os eucalyptos que acabamos de mencionar, eleva-se excepcionalmente a $50^{\circ} \mathrm{C}$. á sombra e $73^{\circ}$ ao sol.

\section{SALGUEIRO DO DESERTO (SALIX ACUTIFOLIA)}

Nas regiões silicosas, desertas, da parte sudoeste da Russia, como na Asia Central, cresce um salgueiro extraordinariamente resistente contra o calor e a secca, que os botanicos denominaram Salix acutifolia. Quando todas as outras arvores seccam sob a influencia do calor ardente do sol e do vento do deserto, esse salgueiro conserva-se viridente, em virtude da formação peculiar das suas folhas que têm dupla camada cellular, assim como, em consequencia da vellosidade dos galhos, propriedades essas que difficultam a transpiração.

Introduziram-no recentemente na America do Norte, para cultival-o nas regiões a oéste do Missouri, que por causa da pequena precipitação aquosa não possuem arvore alguma.

Indagando-se da utilidade desse salgueiro, verifica-se que fornece lenha, e que será relativamente de pequeno valor, porém, inestimavel no deserto. Os seus galhos podem servir para fazer grades de vime, cestas, sebes entrek: zadas, assim como para a producção do humus no sólo mais esteril, preparando-o mesmo desta maneira para a cultura dos vegetaes mais exigentes. A propagação por estacas é muito facil. (Pertence á familia das Salicinaceas).

Em sólo fertil desenvolve-se, tornando-se arvore bella e vistosa.

\section{LIRIO DO COLORADO (HESPEROCALLIS INDULATA)}

Não é planta "util" do deserto. Pelo menos por emquanto não lhe conhecemos utilidade alguma, que ainda póde ser descoberta. E' certamente de belleza rara e, por isto, a mencionamos aqui.

De todas as plantas favoritas da natureza, por certo não ha outra mais predestinada a alegrar os sentidos do homem no jardim das flores do deserto, do que o Lirio do Colorado. Como diz o seu nome, a sua patria está no deserto quente, arenoso e triste do Colorado, que muitas vezes, durante alguns annos, recebe apenas chuva insignificante. Nesses tempos o raiz (cebola) dorme na profundidade da terra dez até doze annos, para depois do primeiro aguaceiro penetrante, surgir da areia núa, sem sombra, uma haste floral, de 60 até 90 centimetros de altura, ornada e rodeada de compridas folhas verde-escuras, profundamente unicronadas. Um botão vem após outro, talvez 30 até 40, e quando desabrocham as flôres, outros se formam na haste, que continúa a crescer, levando seis semanas com essa força productora, ininterruptamente. As fiôres compostas de seis petalas têm o dianietro de cerca de oito centimetros; as petalas têm alvura brilhante, sendo a nervura mediana de côr purpureo-esverdeada. De côr de leite quando desabrocham, tcrnam-se no correr do dia, de côr branco-perola e delicadamente translucidas á tarde - a phase de sua maxima belleza. As campanulas bellas, como nos contos de fadas, dobram as suas petalas desbotadas á meia noite, para dar logar a outras similares, que com a aurora se desenvolvem, encantadoras de mocidade, como a Aphrodite que acaba de nascer das brancas espumas do mar. Dahi o seu nome generico: Hesperocallis - belleza da tarde. 
Um exemplar grande apresenta por dia cinco a seis flores bem desabrochadas, que desde o momento do desdobramento e, particularmente á tarde, exhalam perfume suavissimo.

A flôr produz uma capsula triangular de cerca de tres centimetros de comprimento, cheia de sementes pretas, que sem duvida se conservam por muito tempo, porque, ás vezes, só podem germinar depois de passados muitos annos de estiagem. Os bulbos da espessura de dois até cinco centimetros, encontram-se pouco mais ou menos em uma profundidade de 30 centimetros, pelo que escapam á destruição do calor ardente do sol durante as prolongadas sêccas e, ao mesmo tempo, á extincção pelos indios, que assiduamente cavam na terra silicosa do deserto para colher os bulbos desse lirio, que chamam "ethulia", quando faltam as vagens do mesquito.

Trata-se de saber que sentido ligan a essa palavra. Os mesmos indios comem muitas vezes larvas para resistir á fome; as larvas, pois, são neste caso uteis aos indios.

L,embrando-nos das condições peculiares $\mathrm{s}$ b b as quaes essa planta vegeta, não póde surprehender-nos o facto de ser ella a unica representante de um genero bem distincto da ordem das Liliaceas.

Sendo o lirio do Colorado tão ameno, como filho silvestre do deserto, que belleza não desabrochará na mão carinhosa do homem!?

De certo numero de plantas que preenchem o fim que temos em vista, apenas falta mencionar a Agave americana e A. mexicana, que crescem em sólo vulcanico secco, do Mexico, Arizona e California meridional, e que nas suas folhas fornecem uma fibra procurada. O olho da haste floral do tamanho de uma cabeça, sendo carbonizado, fornece uma fina substancia de tinturaria, de côr preta ; sendo cortado bem novo e cozido n'agua dá um bom xarope. Assado, fórma um alimento que tem muitos apreciadores. Sendo cortado pouco antes de nascer a haste e praticando-se no mesmo logar uma cavidade, junta-se na bacia assim formada o summo, que póde servir para distillar aguardente.

A bayonetta hespanhola (Yucca baccata) prospéra em sólo silicoso pobre. Seus fructos, produzidos, de dois en dois annos, de um até seis, são qualificados como bananas em certas regiões, porque quando maduros se assemelham, na fórma e tamanho, áquelles fructos. A sua côr é amarella e a polpa, em que se encontram grandes sementes pretas, é doce e saborosa. Quando verdes se assam nas cinzas quentes como batatas. Os olhos floraes, colhidos pouco antes de desabrocharem, se assam tambem e neste estado são considerados acepipe. Das folhas se extrahe uma fibra grosseira, mas duradoura. Essa planta, afinal, é procurada e utilizada para sebes.

A Agave sisalana, que cresce em sólo pedregoso, magro, da peninsula do Yucatão, e fornece o excellente canhamo-sisal, merece ser estudada. Por ter ficado até hoje limitada a essa distribuição geographica, estreita, não se póde concluir que os ensaios de introduzil-a em outra região serão mal succedidos. 
A transplantação dessa agave em condições similares teria talvez bom exito quanto á vegetação, mas de antemão não se póde julgar, qual será a qualidade da fibra. Sómente os ensaios de cultura podem esclarecer-nos a respeito, e em geral destes depende a introducção de qualquer cultura planejada. E' natural a probabilidade do exito, porém, si a houver, para nada servem as theorias e opinião dos outros. Existindo a probabilidade, ninguem poderá prophetizar o resultado de um ensaio de introducçãu de uma nova cultura. E' o caso do axioma antigo: "experimentar vale mais do que estudar". Com resolução energica se devia proceder á cultura em pequena escala, para que em caso de insuccesso não haja a lamentar prejuizos pecuniarios.

Uma outra planta textil, o esparto, que prospéra nos terrenos mais seccos da Hespanha e da Africa Septentrional, merece tambem ser mencionada aqui. Devemos attenção especial ao pandano, muitas vezes o primeiro cclono nas ilhas de coraes que acabam de formar-se no Oceano Pacifico. E' tambem uma planta textil.

Ainda lembraremos as acacias australianas, que fornecem a cortiça de mimosas, muito procurada. Os desertos de areia que recebem pequena quantidade de humidade, mesmo pelas neblinas que vêm do mar, poderão tornar-se muito uteis com a cultura dessas arvores, a que se póde associar para os climas quentes a accacia arabica. Ella não sómente fornece a gomma conhecida, mas tambem a sua cortiça é empregada nos cortumes.

Da Y ucca brevifolia é sabido que o seu caule é uma materia prima procurada para a fabricação do papel. E' encontrada em maior numero nos desertos de Mojave e Colorado, desertos unidos, muito pobres de agua e muito ricos de areia e alcalis.

Não seria lucrativo o estabelecimento de bosques de yucca nas regiões mais pobres do deserto na zona subtropical, as quaes, por sua situação, tornam possivel concorrer vantajosamente pela exportação dos productos respectivos com outros similares?

\section{CASAS QUE NEGOCIAM COM SEMENTES, RHIZOMAS E ESTACAS DE PLANTAS TROPICAES}

Para remover difficuldades na obtenção de sementes, rhizomas e estacas de plantas tropicaes no paiz, completamos esse tratade de cultura de vegetaes com uma lista de casas que negociam nessa especialidade. Cremos, assim, facilitar as tentativas de ensaios de cultura e da introducção de bôas variedades notaveis. Por certo, as melhores intenções de fomentar a agricultura de uma região tropical pela introducção de novas plantas uteis ou de novas variedades de plantas já cultivadas, naufragaram sómente porque não se soube obter o material necessario para a sementeira. O agricultor da zona temperada não conhece essa difficuldade, porque o negocio da venda de sementes, rhizomas e estacas é muito desenvolvido. Esse commercio só se faz em pequena escala, nos paizes tropicaes, o que tanto mais se sente, porque as compras em geral se fazem em logares longinquos e de diversas regiões, para que tenham bom exito. 
Casas que negociam em sementes, rhizomas e estacas de plantas tropicaes

\begin{tabular}{|c|c|}
\hline FIRIMAS & RESIDENCIAS \\
\hline Hirain Sibley \& C... & $\begin{array}{l}\text { Rochester, Estado de Nova } \\
\text { York. }\end{array}$ \\
\hline Ellwanger \& Barry...... & Idem, idenr............. \\
\hline J. H. Alexander.... & Augusta, Est. de Georgia... \\
\hline P. J. Berkmans......... & Augusta, Est. de Georgia... \\
\hline Dan. Talmage's Sons \& C. & $\begin{array}{l}\text { Nova-Orléans, Est. de Lui- } \\
\text { siana. }\end{array}$ \\
\hline Ricliard Frotscher....... & $\begin{array}{l}\text { Nova-Orléans, Esst. de Lui- } \\
\text { siana. }\end{array}$ \\
\hline R. H. S. Martin........ & $\begin{array}{l}\text { Nova-Orléans, Est. de Lui- } \\
\text { siana. }\end{array}$ \\
\hline W. Atlee Burpee \& C... & Philadelphia............. \\
\hline Henry Eiggert.......... & S. Luiz, Est. de Missouri... \\
\hline F. Roeding. & Fresno, Est. da California \\
\hline
\end{tabular}

\section{ARTIGOS QUE VENDEM}

Sementes de milho, sorgo, fumo, algodoeiro, ervillas, de diversas gramineas subtropicaes e de arvores das florestas norte-americanas.

Plantinhas e garfos de pecegos, nectarinas, figueiras, todas as fructeiras norte-americanas.

Sementes dealgodoeiro; principalınente da variedade peterkin, assim como de plantas cultivadas, subtropicaes.

Plantinhas de "loquats", ameixas - Sinão, Kakis, Romeiras, pecegos chinêses, vides de "scuppernong" e variedades similares.

Sementes de arroz da Carolina.

Sementes de vegetaes subtropicaes para jardins.

Sementes de diversas variedades de algodoeiro.

Sementes de milho, pimenta vermelha, sorgo, inhame chinês, tomates, teosinto. Vende tambem bôa variedade de perá : mammoth bronze.

Sementes de plantas norte-americanas, que não se consideram uteis, nomeadamente de videiras silvestres.

Plantinhas de figueiras, aroeiras, amendoeiras, pecegos, nespereiras japonicas, kakis, oliveiras, laranjeiras, limoeiros, grenadillas, goiabeiras, pitangas.

John Grelck \& C.. ..... Los Angeles, Fist. da California.

Plantinhas de pitangas, goiabeiras, pepinos ou pereiras-melões, (Solanum Guatemalense), laranjeiras e limoeiros.

Th. A. $\operatorname{Cox} \&$ C........ San Francisco, Est. da Cali-

Sementes de plantas subtropicaes para jardim e de arvores florestaes da California; plantinhas de kakis, romeiras, oliveiras, laranjeiras, limoeiros, limettas, figueiras, hovenias, (Hovenia dulcis) pecegueiro.

J. C. Lemmon (Lemmon Oakland, Est. da California Sementes de plantas da costa do Pacifico, que não se consideram em geral plantas cultivadas.

B. W. Hawkius \& C....

Denis Station, Fist. de Georgia.

W. W. Hawkius $\&$ Sons .

Lake George, Est. da Florida.

T. Roberto Kirste11.

S. Paulo, Brasil

Sementes de algodoeiro e milho. Eispecialidade.

Plantinhas e sementes de laranjeiras, limoeiros, kakis, figueiras, pecegueiros, nogueiras-pecan, amoreiras, bananeiras.

Sementes e plantinhas de todos os vegetaes do Estado de S. Paulo e do Brasil Austral.

L. Albuquerque (Beliche) Rio de Janeiro (Inha氏́ma). Rua dos Pilares, 2. Caixa do Correio, 874 .

Sementes do beliclıe. Introducção e experimentação de sementes, aniniaes de raça e instrumentos agricolas. 


\section{Casas que negociam em sementes, rhizomas e estacas de plantas tropicaes}

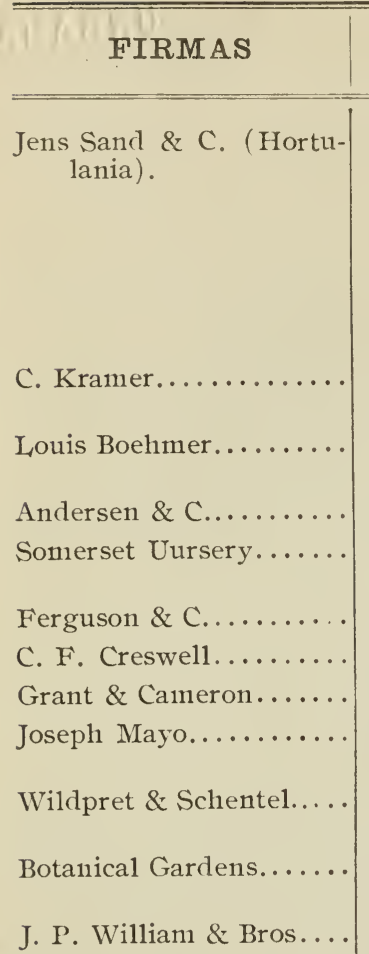

J. P. William \& Bros....

E. B. Creasy ...........

Fred. Tathan1..........

George Freese..........

E. Fünfgeld \& C........

Robert Hesse.........

Julio Frölich y Jimenez.

Emil Florke \& C.......

P. \& E. Transon........

William Bull...........

A. Loureiro............

Abel Ribeiro \& C.......

Alberto Gonies \& C......

\section{RESIDENCIAS}

Rio de Janeiro (Capital Federal). Rua do Ouvidor, 45 .

Yokohama, Japão........

Yokohama, Japão........

Sidney, Australia......

Paramatta, Nova-Ga11es do Sul.

Double Bay near Sidney.

Melbourne, Australia....

Melbourne, Australia....

Drury, Nova Zelandia, perto de Auckland.

Orotava na Teneriffa......

Gennesh Khind em Poonah, Indias.

Heneratgoda, Ceylão......

Colombo, Ceylão..........

Yarrow, Ceylão...........

Bogota, Colon bia.........

Saigon, Cochinchina......

Tiflis, Caucaso...........

Cartagena, Hespanla.....

Léon, Nicaragua.... .....

London, 155. Fenchurchstreet.

London, Kingsroad, Chelsea.

Rua Eistacio de Sá, 8. Rio de Janeiro, Brasil.

Rua da Carioca, 28. Rio de Janeiro, Brasil.

Rua do Hospicio, 20. Rio Idem, iden.
ARTIGOS QUE VENDEM

Sementes novas de hortaliças, flôres e plantas cultas, de rlantas de ornamentação, fructeiras roseiras, dhalias, bulbos, batatas e rlizomas, sortimento de ferragens, utensilios e objectos para jardinagen, etc., pulverizadores para o tritamento das vides, etc.

Sementes e plantinlias de todas as plantas desejadas do Japão.

Sementes e plantinhas de todas as plantas japonicas.

Sementes e plantinhas de vegetaes australianos.

Plantinhas de arvores subtropicaes.

Sementes e plantinhas de vegetaes subtropicaes e tropicaes.

Sementes e plantinhas de vegetaes indianos.

Sementes de Chinchonas, palıeiras, cafeeiros, croton, sappan, dividivi, acacias arabicas, cardamomos, cacaoeiros, maniçobas, plantinhas (acondicionadas em caixas de Wardeau) de muscaliros, seringueiras, mangostanas e ananazeiros.

Conmissario, que executa todas as ordens sobre material para a senenteira, que se vende nas Indias e em Ceylão.

Sementes de propria criação, da Chiıcliona Ledgeriana.

Sementes e plantinhas dos vegetaes tropicaes e subtropicaes da Colombia.

Exportadores, que executam ordens sobre sementes e plantinhas.

Commissario, que remette 111aterial para a sementeira por ordem.

Idem, idem.

Idem, iden11.

Sementes e plantinlias de vegetaes tropicaes.

Idem, idem.

Sementes de flores, lıortaliça, rlizo111as, etc.

Idem, idem. de Janeiro, Brasil. 
Casas que negociam em sementes, rhizomas e estacas de plantas tropicaes

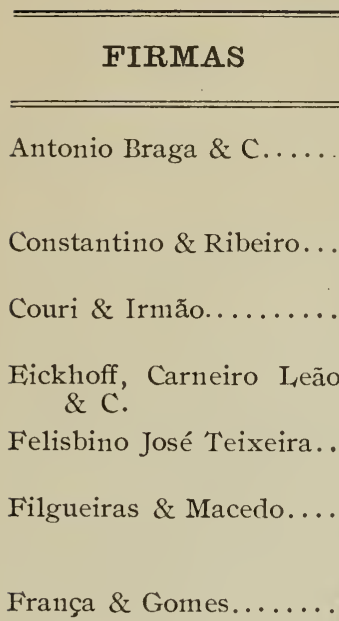

Gonçalves Almeida \& C.

Guimarães \& Fonseca...

H. Moraes

J. A. Monteiro

J. L. Moreira Fangeres. .

James Magnus \& C......

Lopes \& Freire........

Marçal Duarte \& C......

Mendes, Raupp \& Martins

Paulo Cordeiro.........

Pedrosa, Monteiro \& C. .

Pinto Lucena \& C......

Ramos \& $C$...........

Sabroza \& C..........

Schlick \& C..........

Seraphin Ferreira Lopes

Tavares Pereira \& Soares

Teixeira Couto

\section{RESIDENCIAS}

Ruas da Candelaria, 28 e Sementes de flores, hortaliça e rhizoGeneral Camara, 25. Rio mas, etc. de Janeiro, Brasil.

Rua do Ouvidor, 26. Rio Idem, iden. de Janeiro, Brasil.

Rua da Alfandega, 254. Rio Iden, idem. de Janeiro, Brasil.

Rua do Ouvidor, 77. Rio de Idem, idem. Janeiro, Brasil.

Rua de Sant'Anna, 71. Rio Idem, idem, de Janeiro, Brazil.

Ruas do Rosario, 73 e Becco Idem, idem. das Cancellas, 11. Rio de Janeiro, Brasil.

Ruas do Mercado, 27 e Ou- Idem, iden. vidor, 21. Rio de Janeiro, Brasil.

Ruas Gonçalves Dias, 89 e Idem, idem. Rosario, 165. Rio de Janeiro, Brasil.

Rua Uruguayana, 128 e 130. Idem, idem. Rio de Janeiro, Brasil.

Rua Ouvidor, 63. Rio de Idem, iden. Janeiro, Brasil.

Rua da Candelaria, 49. Rio Idem, idem. de Janeiro, Brasil.

Rua Senador Euzebio, 148. Idem, idem. Rio de Janeiro, Brasil.

Rua S. Pedro, 96. Rio de Idem, idem. Janeiro, Brasil.

Rua da Quitanda, 73. Rio Idem, idem. de Janeiro, Brasil.

Rua Visconde Itauna, 111. Idem, idem. Rio de Janeiro, Brasil.

Rua do Ouvidor, 57. Rio de Idem, idem. Janeiro, Brasil.

Rua Conde de Bom fim,1181. Idem, idem. Rio de Janeiro, Brasil.

Rua do Hospicio, 24. Rio Idem. idem. de Janeiro, Brasil.

Ruas do Ouvidor, 33 e Ro- Idem, idem. sario, 108 . Ria de Janeiro, Brasil.

Rua S. João Baptista, 38. Idem, idem. Rio de Janeiro. Brasil.

Rua da Candelaria, 1. Rio Idem, iden. de Janeiro, Brasil.

Rua do Ouvidor, 61. Rio de Idem, idem. Janeiro, Brasil.

Rua do Cattete, 68. Rio de Idem, idem. Janeiro, Brasil.

Rua do Hospicio, 81. Rio Idem, idem. de Janeiro, Brasil.

Rua Uruguayana, 99. Rio Idem, idem. 


\section{Casas que negociam em sementes, rhizomas e estacas de plantas tropicaes}

\begin{tabular}{|c|c|c|}
\hline FIRMAS & RESIDENCIAS & ARTIGOS QUE VENDEM \\
\hline Damine Giuseppe....... & $\begin{array}{l}\text { Rua Coronel Rodovalho, } 9 . \\
\text { S. Paulo, Brasil. }\end{array}$ & $\begin{array}{l}\text { Sementes de flores, hortaliças, rhizo- } \\
\text { nias, te. }\end{array}$ \\
\hline Garcia Nogueira \& C.... & $\begin{array}{l}\text { Rua Piratininga, 100. São } \\
\text { Paulo, Brasil. }\end{array}$ & Iclen, irlem. \\
\hline João Gonçalves ........ & $\begin{array}{l}\text { Rua Campos Salles, } 47 \text {. São } \\
\text { Paulo, Brasil. }\end{array}$ & Idem, idem. \\
\hline Loureiro, Costa \& C..... & $\begin{array}{l}\text { Rua S. Bento, } 41 \text { B. São } \\
\text { Paulo, Brasil. }\end{array}$ & Idem, idem. \\
\hline Miguel Pinani......... & $\begin{array}{l}\text { Rua S. Bento, } 47 . \text { S. Paulo, } \\
\text { Brasil. }\end{array}$ & Idem, idem. \\
\hline Quirino Sarto.......... & $\begin{array}{l}\text { Ladeira Coronel Rodova- } \\
\text { 1ho, 37. S. Paulo, Brasil. }\end{array}$ & Idem, idem. \\
\hline R. Sucena \& C........ & $\begin{array}{l}\text { Rua do Rosario, 21. São } \\
\text { Paulo, Brasil. }\end{array}$ & Idem, iden. \\
\hline Setimo Gosolli........ & $\begin{array}{l}\text { Rua Canıpos Salles, 5.5. São } \\
\text { Paulo, Brasil. }\end{array}$ & Idenı, idem. \\
\hline Silva Neves... & $\begin{array}{l}\text { Mercado Central, } 96 \text { e } 98 \\
\text { S. Paulo, Brasil. }\end{array}$ & Idem, idenı. \\
\hline $\begin{array}{l}\text { Rodrigo de Azevedo } \mathrm{Ne}- \\
\text { ves. }\end{array}$ & $\begin{array}{l}\text { Avenida B, 15. S. Paulo } \\
\text { Brasil. }\end{array}$ & Idem, idem. \\
\hline Antonio H. Pinheiro ... & $\begin{array}{c}\text { Rua dos Andradas, } 493 . \text { Rio } \\
\text { Grande do Sul, Brasil. }\end{array}$ & Idem, idenı. \\
\hline Augusto Gracther....... & $\begin{array}{c}\text { Rua dos Andradas, } 306 . \text { Rio } \\
\text { Grande do Sul, Brasil. }\end{array}$ & Idem, iden. \\
\hline Jacob Hemb.......... & $\begin{array}{c}\text { Rua dos Andradas, 299. Rio } \\
\text { Grande do Sul, Brasil. }\end{array}$ & Idem, idem. \\
\hline Krahe \& C............ & $\begin{array}{l}\text { Rua dos Andradas, } 497 \text { e } \\
\text { 501. Rio Grande do Sul, } \\
\text { Brasil. }\end{array}$ & Idem, idem. \\
\hline Oscar Cruz............ & $\begin{array}{l}\text { Rua dos Andradas, } 463 . \text { Rio } \\
\text { Grande do Sul, Brasil. }\end{array}$ & Idem, idem. \\
\hline Schanwaad \& Deutrich.. & $\begin{array}{l}\text { Rua dos Andradas, } 549 . \text { Rio } \\
\text { Grande do Sul, Brasil. }\end{array}$ & Idem, idem. \\
\hline $\begin{array}{l}\text { Alexandre Cardoso de } \\
\text { Souza. }\end{array}$ & $\begin{array}{l}\text { Rua Santos Dumont, 4, } \\
\text { districto da Conceição. } \\
\text { Bahia, Brasil. }\end{array}$ & Idem, idem. \\
\hline Francisco Weigang.. & $\begin{array}{l}\text { Rua do Riachuelo, } 67 . \mathrm{Pa}- \\
\text { raná, Brasil. }\end{array}$ & -Idem, idem. \\
\hline $\begin{array}{l}\text { Sylvio Colle \& Valnuas- } \\
\text { soni. }\end{array}$ & $\begin{array}{l}\text { Rua do Riachuelo. Paraná, } \\
\text { Brasil. }\end{array}$ & Idenı, idenı. \\
\hline
\end{tabular}

\section{NOTA}

Em geral os consules brasileiros nos diversos paizes prestam-se a dar informações e encarregar-se da remessa de sementes, plantinhas, rhizomas ou quaesquer encommendas pedidas directamente por qualquer brasileiro, o que é de grande utilidade para a agricultura intertropical dos Estados Unidos do Brasil. 
UNIVERSTTY OF ILLINOIS-URBANA

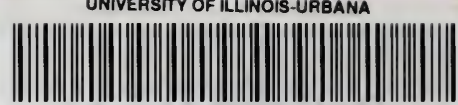

30112072543090 